\title{
Greenhouse Gases Emissions in Agricultural Systems and Climate Change Effects in Sub- Saharan Africa
}

\author{
Winnie Ntinyari and Joseph P. Gweyi-Onyango
}

\section{Contents}

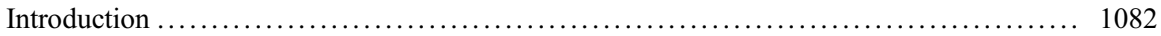

The Approach Used ................................................. 1084

Key Strategies for Reducing Greenhouse Gases Emissions and Mitigation of Climate

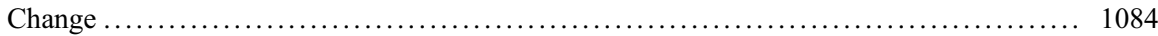

Adopting Improved Nutrient Management in the Agricultural Lands ................ 1084

Proper Management of Residue and Adoption of Appropriate Tillage Methods ........ 1086

Introduction of Carbon-Sequestrating Grass Species ............................ 1087

Livestock and Manure Management Strategies in SSA ........................ 1088

Adopting Bioenergy as GHG Emission Reduction Strategy ....................... 1092

Reduction of GHG Through Genetic Selection of Animals ........................ 1094

Adopting to Isotopic Tracers in the Agricultural Field ........................... 1094

Management of Emissions in Rice by Adoption of Efficient Varieties ............... 1095

Development of Flexible Technology-Forcing Regulations ...................... 1096

Minimizing Enteric Fermentation and Food Wastes ............................ 1097

Use of Biochar to Minimize GHG Emissions ................................. 1097

Compositing of Solid Manure Before Applying to Crop Fields ................... 1098

Integrated Farming Systems ........................................... 1099

Barriers to Mitigation GHG Emission and Climate Change in Sub-Saharan Africa ..... 1100

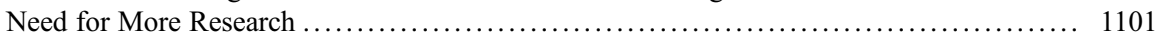

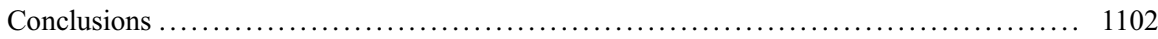

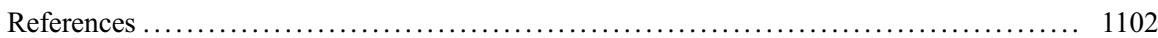

This chapter was previously published non-open access with exclusive rights reserved by the Publisher. It has been changed retrospectively to open access under a CC BY 4.0 license and the copyright holder is "The Author(s)". For further details, please see the license information at the end of the chapter.

W. Ntinyari $(\bowtie) \cdot$ J. P. Gweyi-Onyango

Department of Agricultural Science and Technology, Kenyatta University, Nairobi, Kenya

e-mail: gweyi.joseph@ku.ac.ke 


\section{Abstract}

Climate change has been viewed to result from anthropogenic human activities that have significantly altered the Nitrogen $(\mathrm{N})$ cycle and carbon cycles, increasing the risks of global warming and pollution. A key cause of global warming is the increase in greenhouse gas emissions including methane, nitrous oxide, and carbon among others. The context of this chapter is based on a comprehensive desktop review on published scientific papers on climate change, greenhouse emissions, agricultural fertilizer use, modeling and projections of greenhouse gases emissions. Interestingly, sub-Saharan Africa (SSA) has the least emissions of the greenhouses gases accounting for only $7 \%$ of the total world's emissions, implying that there is overall very little contribution yet it has the highest regional burden concerning climate change impacts. However, the values could be extremely higher than this due to lack of proper estimation and measurement tools in the region and therefore, caution needs to be taken early enough to avoid taking the trend currently experienced in developed nations. In SSA, agricultural production is the leading sector in emissions of $\mathrm{N}$ compound to the atmosphere followed by energy and transportation. The greatest challenge lies in the management of the two systems to ensure sufficiency in food production using more bioenergy hence less pollution. Integrating livestock and cropping systems is one strategy that can reduce methane emissions. Additionally, developing fertilizer use policy to improve management of fertilizer and organic manure have been potentially considered as effective in reducing the effects of agriculture activities on climate change and hence the main focus of the current chapter.

\section{Keywords}

Modeling $\cdot$ Pollution $\cdot$ Environment $\cdot$ Mitigation $\cdot$ Nitrous oxide $\cdot$ Carbon dioxide $\cdot$ Methane

\section{Introduction}

Globally, agriculture is the main contributor to greenhouse gases emissions (GHG) that is estimated to be between $10 \%$ and $20 \%$ of the total anthropogenic GHG emissions (Allen et al. 2020). From a baseline scenario, it is projected that GHG emissions from agriculture will be 1.7 gigatonnes by 2050 . The GHG concentration especially $\mathrm{CO}_{2}$ has increased by $40 \%$ since preindustrial times due to fossil fuels burning and also land-use changes. Current arable land cultivation practices have raised a great concern on the increase of GHG to the atmosphere. In sub-Saharan Africa, the effects are quite crucial but diverse as it has been associated with the variations of the season (rainy and dry) (Awazi and Tchamba 2019). As a result, this has significantly impacted the level of productivity, leading to food insecurity in this region. According to the US Environmental Protection Agency in 2010, the agricultural sector is the leading source of global GHG and accounts for $53 \%$ of carbon dioxide $\mathrm{CO}_{2}$ emissions (Ronaghi et al. 2018). The distribution of $\mathrm{CO}_{2}$ emissions is 


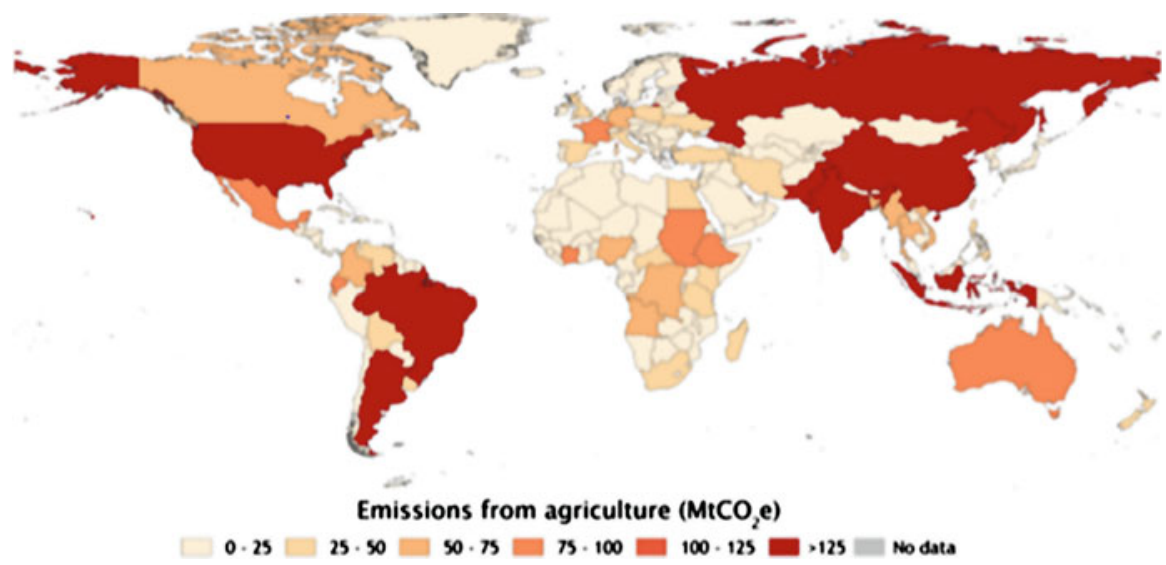

Fig. 1 Showing contribution of agriculture to GHG emission in global perspective. (Adapted from Malaka 2017)

globally spread as shown in Fig. 1, with most of sub-Saharan African countries emitting in the ranges of $0-75 \mathrm{MtCO}_{2} \mathrm{e}$.

The main four sources of emissions from the agricultural sector include cropland soil management, rice cultivation, ruminant livestock enteric fermentation, and livestock manure management (Beach et al. 2015). According to Tongwane and Moeletsi (2018), half of Africa's total agricultural emissions were from enteric fermentation in 214 which signifies how great this source is. The GHG emissions in sub-Saharan Africa are estimated using Intergovernmental Panel on Climate Change guidelines in various subsystems of agriculture including crop production, animal manures, and methane emissions from livestock.

The main GHG fluxes from agricultural land include nitrous oxide $\left(\mathrm{N}_{2} \mathrm{O}\right)$, carbon dioxide $\left(\mathrm{CO}_{2}\right)$, and methane $\left(\mathrm{CH}_{4}\right)$. The emissions of these gases $\left(\mathrm{CH}_{4}\right)$ and $\left(\mathrm{N}_{2} \mathrm{O}\right)$ in agricultural land have increased by $17 \%$ from 1990 to 2005 globally (Popp et al. 2010). It is also anticipated that the GHG emissions will increase soon due to modern land-use changes that the sub-Saharan Africa region has adopted (Popp et al. 2010). Although the fluxes are anticipated to be high, there are various uncertainties in the estimates provided due to large insufficient temporal and spatial representation of emissions from agricultural soils (Mwanake et al. 2019). In SSA, these changes have significantly impacted the climatic patterns leading to more extended droughts and excessive rainfall that does not support agricultural productivity at the field level. Furthermore, organic soils are important sources of GHG emissions with about 35 thousand Giga grams of $\mathrm{CO}_{2}$ as of 2010 demonstrated in SSA (Malaka 2017). Though there is no clear quantification data, there no doubt that there are some emissions from due to lack of management of crop residues since most of the agricultural waste in the land is openly burned or left free for livestock grazing. The burning of savannas and grassland fires that is common with the sub-Saharan African region is another greater contributors to GHG emissions (Malaka 2017). Due to this huge contribution of GHG emissions to the ecosystems, agriculture becomes an integral part that SSA and the whole globe should focus on to stabilize the 
emissions and save the current and future generations from the devastating effects of climate change. Therefore, this chapter will explore several available options and strategies that have the potential of mitigating GHG emissions from agriculture and minimize the impact of climate change.

\section{The Approach Used}

To acquire information of this chapter, we used the Google Scholar search engine to identify relevant peer-reviewed research articles published in high impact journals. A total of 53 articles were used that ranged from experimental, reviews, and policy papers. Keywords used in Google Scholar search engine were sub-Saharan Africa, GHG, emissions, management of emissions from the agriculture sector, climate change, agricultural sectors, management, agricultural systems, modeling, emissions, and global warming. The chapter focused broadly on various methods that have been suggested by the global panel, policies, and guidelines of the Intergovernmental Panel on climate change.

\section{Key Strategies for Reducing Greenhouse Gases Emissions and Mitigation of Climate Change}

\section{Adopting Improved Nutrient Management in the Agricultural Lands}

In sub-Saharan Africa, there is a problem of declining nutrient levels in cultivatable land which is due to poor nutrient management among the farmers. Most of the farmers lack the know-how on efficient use of the available fertilizers with minimal $\mathrm{N}$ loss but with improved crop yield (Galloway et al. 2003). To achieve this, farmers should be enlightened through policies and extension on various ways of fertilizer use that minimize the extent of nutrient loss to the environment that contribute to emissions of gases such as nitrous oxide (Huang et al. 2019). Improvement of nutrient use efficiency has a high potential of minimizing the $\mathrm{N}_{2} \mathrm{O}$ emissions from cropland that are generally generated by the soil microbes from the surplus of $\mathrm{N}$ and indirect emissions from carbon dioxide from fertilizer companies (Galloway et al. 2003). Some of the recommended practices that farmers can adopt lie in the $4 \mathrm{R}$ principle, which entails the use of the right source (fertilizer with higher efficiency), right rate, right timing, and right placement as expounded by Cassman et al. (2003). The proper placements of these fertilizers lead to fewer losses since there is a concomitant improvement in the plant uptake through making nutrients more accessible by the roots hence restricting available pathways for emissions. An important viable option for reducing losses is by reducing nitrification. Use of nitrification inhibitors for the case of nitrogen use is a promising strategy that has the huge potential of slowing the release processes that contribute to the formation of $\mathrm{N}_{2} \mathrm{O}$ emissions (Coskun et al. 2017). Use of improved crop varieties with higher $\mathrm{N}$ uptake and use efficiencies will lead to a reduction in the nutrient loss since such crop 
idiotypes fully utilize the applied and available nutrient for use hence less losses in the form of GHG emissions (Sanz-Cobena et al. 2017).

Improved nutrient management is considered a better and viable strategy to overcome the challenges associated with the impacts of climate change in crop and food insecurities. According to García-Marco et al. (2016), adopting improved agronomic practices can lead to higher yields and promote the generation of more carbon that can be used to increase the soil carbon storage hence fewer losses to the environment. Some of the practices suggested by García-Marco et al. (2016) are extending crop rotations, use of improved varieties as mentioned earlier in this text, and using mixed cropping with perennial crops that will result to more carbon storage underground.

Emissions of GHG can also be reduced through practicing intensive cropping systems that minimize overreliance of pesticides and other agricultural inputs and consequently reduce the extent of emissions to the environment (Hoekman and Broch 2018). Besides, farmers/growers can use the cover crops that provide additional carbon to the soil and may help in extracting the available unused $\mathrm{N}$ by the next crops hence resulting to reduction of $\mathrm{N}_{2} \mathrm{O}$ emissions (Oberthür et al. 2019). Use of Global Positioning Systems (GPS) guidance and variable rate technology are useful in applying inputs and hence allowing farmers to optimize nutrients with consequent less GHG emissions. In addition, the use of slow-release fertilizers such as prilled urea can be an efficient way of reducing $\mathrm{N}_{2} \mathrm{O}$ emissions from cropland. Moreover, the use of biofertilizer has been advocated as an alternative to the more soluble and more reactive $\mathrm{N}$ sources as documented by excellent reviews by Ntinyari and Gweyi-Onyango (2018). Locally available nitrification inhibitors can also be useful in reducing the amount GHG from applied fertilizers to cropping systems. Soil $\mathrm{pH}$ management is also critical towards the management of $\mathrm{N}_{2} \mathrm{O}$ emissions from the soil. Furthermore, the influence of $\mathrm{pH}$ on $\mathrm{N}_{2} \mathrm{O}$ emissions more profound in soils that have high nitrate levels. According to the existing literature, $\mathrm{pH}$ contributes between 3 and 10 folds in incidences denitrification (Šimek and Cooper 2002). However, the good news is that use of liming in management of $\mathrm{pH}$ is something feasible among many farmers within sub-Saharan Africa if given fertilizer subsidies. Liming is a good option since is technically feasible and is affordable at a small scale levels. Nutrient use models are other useful tools in quantifying emissions from respective farms through the nutrient budget methods. These tools are key in estimating farm emissions by considering key components of nutrients inputs and nutrient outputs in given farms. In this case, it can be used to make a rough estimate of the amount of inputs required for specific crops to help in the reduction of emissions. Another option is the use and application of the soil systems budgets which record all the nutrient transformation related to emissions, for example, leaching, denitrification, and ammonia volatilization. This points to the fact that modeling tools are essential in linking the soil nutrients as well as a proxy resource for nutrient management and economic benefits to farmers.

Organic soils also need to be properly managed as they have the highest accumulation of carbon over the years. Avoiding row crops and tubers and deep ploughing using heavy machinery has been pointed out as one of the strategies that reduce the emissions of $\mathrm{N}_{2} \mathrm{O}$ and $\mathrm{CO}_{2}$ (Smith et al. 2008). In sub-Saharan 
Africa, a large fraction of the arable land has been degraded due to soil erosion, loss of organic matter, acidification, and other processes. These have to a greater extent affected the potential of the soil in holding/storing of carbon (Smith et al. 2008). Therefore, there is need for reclaiming land by application of organic substrates like manures, biosolids, reducing tillage, and leaving crop residues in the soils. With these practices in the farm, high nitrogen use efficiency is anticipated and this will minimize the emissions of $\mathrm{N}_{2} \mathrm{O}$.

\section{Proper Management of Residue and Adoption of Appropriate Tillage Methods}

Advancing methods of weed control and machinery used in farming systems is another available way of reducing $\mathrm{N}_{2} \mathrm{O}$ emissions from the soils. This is explained by the fact that soil disturbances tend to stimulate the soil carbon loss through enhanced erosion that result in soil carbon loss. However, the tillage method is dependent on the climatic conditions of the soils, considering that some reduced tillage options may have great effects of $\mathrm{N}_{2} \mathrm{O}$ emissions from cropland (Feng et al. 2018). In tillage systems where growers/farmers retain crop residues, they tend to increase the soil carb since these residues act as precursors of soil organic matter which is a main store of carbon in soils. Mostly in the case where paddy crop growing is practiced, it has been found that no-tillage has a significant decrease in methane $\mathrm{CH}_{4}$ emissions. Furthermore, recycling of crop residues has been reported to be of help in preventing the release and/or deposition of aerosols and GHGs that are generated during burning (Feng et al. 2018). Biomass burning is always thought to be a key contributory factor to climate change since it releases methane in notable amounts. This is a common practice in Kano plains in Western Kenya under rice production. This implies that there is a need to manage fire concerning biomass burning in agricultural fields. Reducing biomass burning will also go a long way in minimizing the emissions of hydrocarbons and reactive nitrogen emissions that react to form tropospheric ozone (Leng et al. 2019). This is explained by the fact that smoke composes of aerosols which can have either warming or cooling effects of the atmosphere, hence directly or indirectly contributing to climate change. In this light, reducing the frequency of or the intensity of fires will contribute to landscape carbon density in soil and biomass. To minimize the emissions, mitigation of the radiant forcing is expected to entail fire suppression strategies such as reducing fuel load through vegetation management and also burning of biomass at the time of year when $\mathrm{CH}_{4}$ and $\mathrm{N}_{2} \mathrm{O}$ are less emitted (Leng et al. 2019).

Crop rotation is advocated since it has given beneficial outcome through improving the quality of soils, with reported overall increment of as much $50 \%$ in terms of organic carbon into soils (Paustian et al. 2019). This practice creates resilience in cropping systems and helps the world to be able to combat climate change effects and hence can be a better option for SSA, where this is practiced already in noticeable scale. Through this approach, it is possible to sequester carbon for long-term storage of the atmospheric carbon. In this regard, this alternative offers the best solution to counter the greenhouse gases emissions in 
the ecosystem. In addition, more yields are obtained from the cropping systems, which helps reduce the direct impacts of climate-related contributions to food insecurity. In soil management, there is also a need to bring in low-cost inhibitors that regulate nitrogen processes in the soils. However, this requires knowledge on the sources of the GHG using various soil microbial process that can help to bring mitigation of the same on board. Diversifying on the crop rotations will also provide another strategy to minimize GHG emissions from agriculture in SSA. Diversification of crops helps in improving the productivity in the different and diverse agro-ecosystems in SSA and also lower the carbon footprint. The choice of these crops can be guided depending on the ecological requirements in various growing zones within the region. Another option in minimizing emissions is through intensifying rotations in cropping systems through fallowing. Fallowing promotes nitrogen mineralization hence increasing available nitrogen for use by crops and minimize the amount of organic matter hence less carbon is stored in the soils. Most of the farmers prefer burning of various crop residues in their farms which contributes to climate change in various ways. It contributes to releases of GHGs like $\mathrm{CH}_{4}$ and also generates hydrocarbon and reactive nitrogen emissions that react to for tropospheric zones. Burning also destroys existing grass and also blackens the soil spoiling its quality and ability to sequester carbon. As a mitigation practice, farmers should rescue the frequency and the extent of fires for less $\mathrm{CH}_{4}$ and $\mathrm{N}_{2} \mathrm{O}$ emissions (Smith et al. 2008).

\section{Introduction of Carbon-Sequestrating Grass Species}

Introduction of improved grasses that have a high level of production or with adaptations to $\mathrm{C}$ allocation to deeper roots has a great potential of increasing the soil carbon (Yang et al. 2019). For instance, using deep-rooted grasses in savannas has been associated with increased rates of carbon accrual hence less is emitted to the atmosphere. Cultivating of legumes into grazing lands has also been associated with the promotion of soil $\mathrm{C}$ storage and perhaps reduces $\mathrm{N}_{2} \mathrm{O}$ emissions (Garnett et al. 2017). Grasses also act as cover crops that have long-term potential for reducing GHG emissions through agriculture that comes from agricultural activities. The grasses have the potential of absorbing and retaining stored carbon in the soil. The roots and shoots of cover crops feed bacteria, fungi, and earthworms and other soil organisms that have a significant contribution to the soil carbon levels over time. In the land that is left fallow, there is a need to convert the lands to grassland to sequester more carbon and create a balance of the carbon in the soils for a longer period. The most beneficial aspects of grassland are that they can stay longer without ploughing hence reducing emissions of $\mathrm{N}_{2} \mathrm{O}$ from the soils. In grasslands, intensity grazing has an influence on the density of the grasses and allocation of carbon into the grass fields. It has been reported that carbon accrual on optimally grazed land has been often greater compared to ungrazed grasslands. Also, irrigation of grasslands has also high promotion of the soil carbon gains. Also alleviating deficiencies of nutrients in grassland through use of fertilizer or other organic amendments will promote carbon soil storage (Smith et al. 2008). 


\section{Livestock and Manure Management Strategies in SSA}

Livestock, specifically ruminants such as cattle and sheep, are important sources of $\mathrm{CH}_{4}$ estimated to $18 \%$ of the global anthropogenic of this gas. In Table 1 , there is a high chance of methane emissions that are more prevalent in the year 2000 compared with those likely to be there in the year 2030. These percentages represent a great share that needs to be mitigated using possible strategies that are available to the local farmers (Swamy and Bhattacharya 2006). According to the current statistics, the current population of livestock is anticipated to increase in 2030 based on the projections with sub-Saharan Africa, leading in the population as demonstrated in Fig. 2 (Herrero et al. 2008). This means that there is a need to come up with strategies for minimizing $\mathrm{CH}_{4}$ from livestock systems. Some of the mitigation practices that can be used to reduce $\mathrm{CH}_{4}$ emissions from livestock rearing include but not limited to improving the feeding practices. Feeding animals with more concentrates other than forages has been reported to reduce the rate of.

$\mathrm{CH}_{4}$ for reducing. Other practices that can be used to minimize the level of $\mathrm{CH}_{4}$ emissions are adding oils to the diet, as this is key in improving pasture quality since it improved animal productivity that reduces the proportion of energy lost as $\mathrm{CH}_{4}$. A high intake of protein feeds is also associated with reduced $\mathrm{N}_{2} \mathrm{O}$ emissions to the environment.

Another strategy of managing livestock methane emissions is the use of specific agents and dietary additives that can have the ability to suppress methanogenesis process. Some of the additives include Ionophores antibiotics that can minimize methane emissions in the livestock systems (Gibson 2002). Halogenated compounds inhibit methanogenic bacteria and their effects although they can have reduced feed intake. These have not yet been used extensively in SSA and have a huge potential of adopting. The bovine somatotropin (bST) and hormonal growth implants do not specifically suppress $\mathrm{CH}_{4}$ formation, but by improving animal performance they can reduce emissions per kilogram of animal product (Cerri 2010), which is also another viable option. Adoption of longer-term management changes and animal breeding will enhance reduction of methane output per kilogram of an animal. With improved animal production efficiency, there are reduced lifetime emissions (Wall et al. 2010). Supplements can also be used in reducing methane emission in the livestock. Some of the supplements include oils, fats, tannins, probiotics, and marine algae. It has been reported that methane abetment between $10 \%$ and $25 \%$ is possible when feeding ruminants dietary oils. Also, plant secondary compounds like condensed tannins have proved to reduce methane production by $13-16 \%$ through curbing the process of methanogens.

Other available methane suppressers that are used in combating protozoal infections. Specialized proteins targeting methane-producing microbes will also constitute an effective alternative towards the management of emission from livestock. Moreover, plant saponins that occur naturally in many of the existing plant families have the potential to reduce methane and can be effective in the current measure towards minimizing the concentration of GHG in the atmosphere. Enteric methane emissions can be reduced through manipulation of the microbial communities in the 


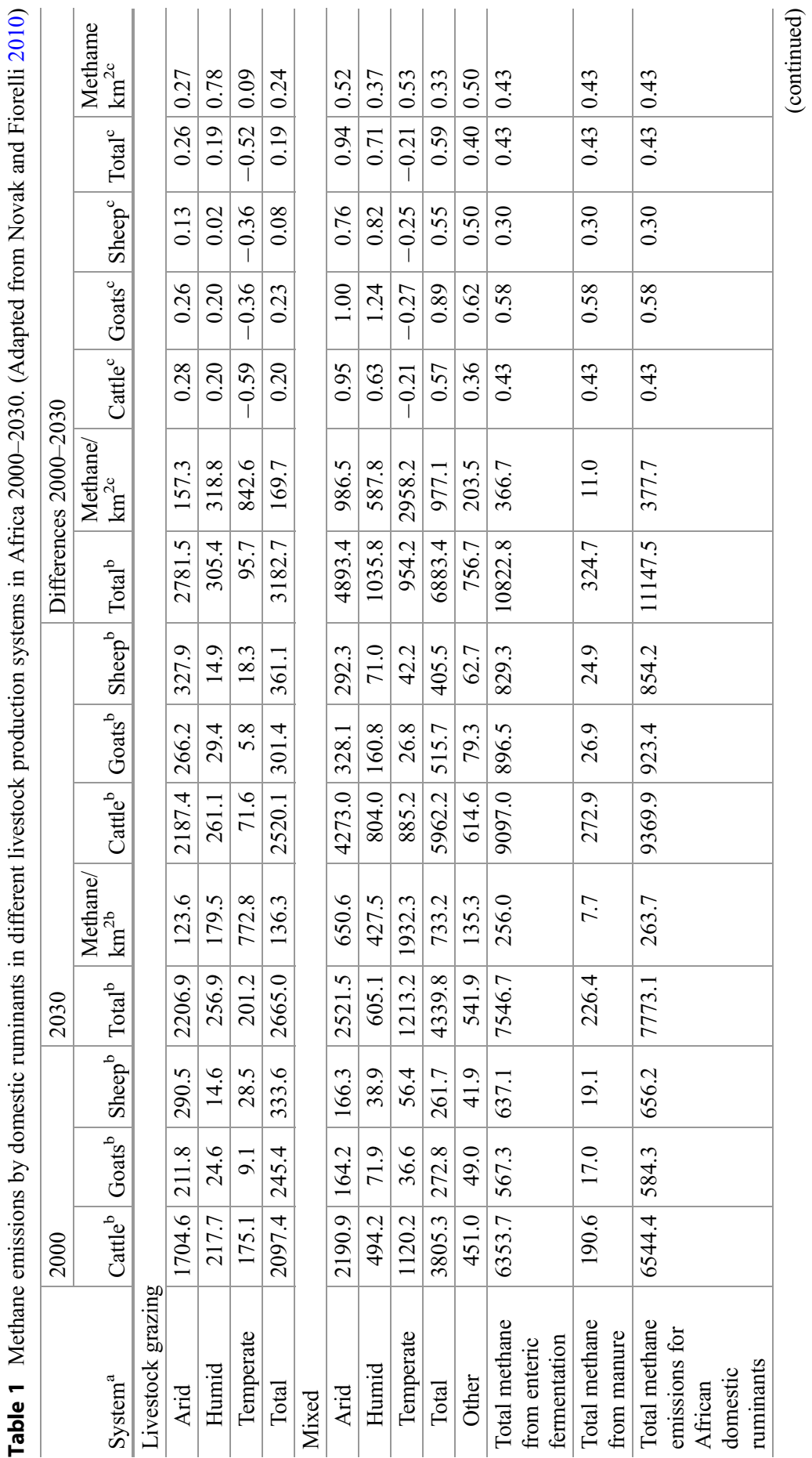




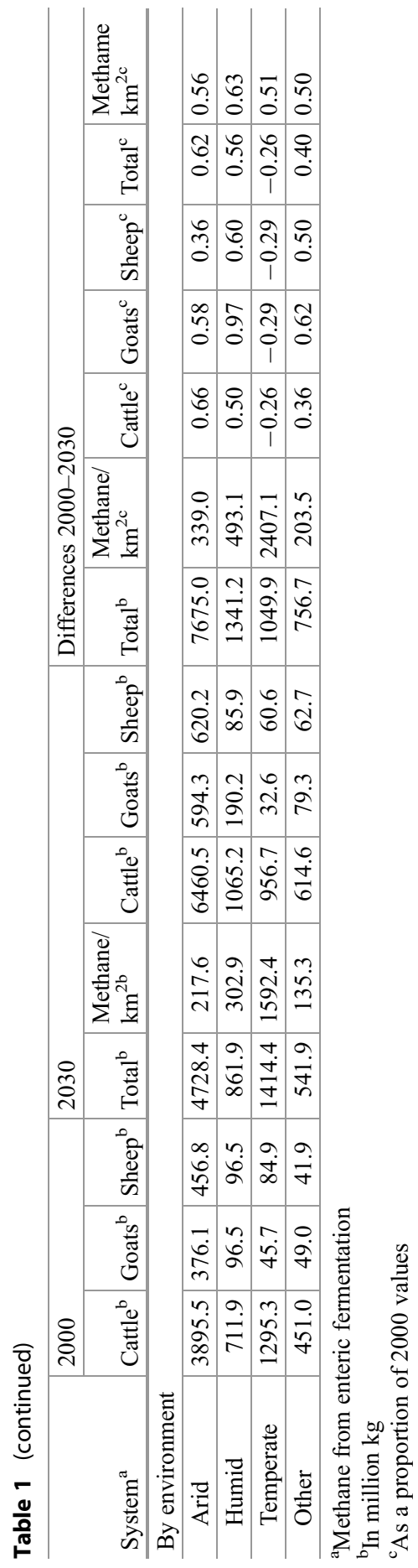



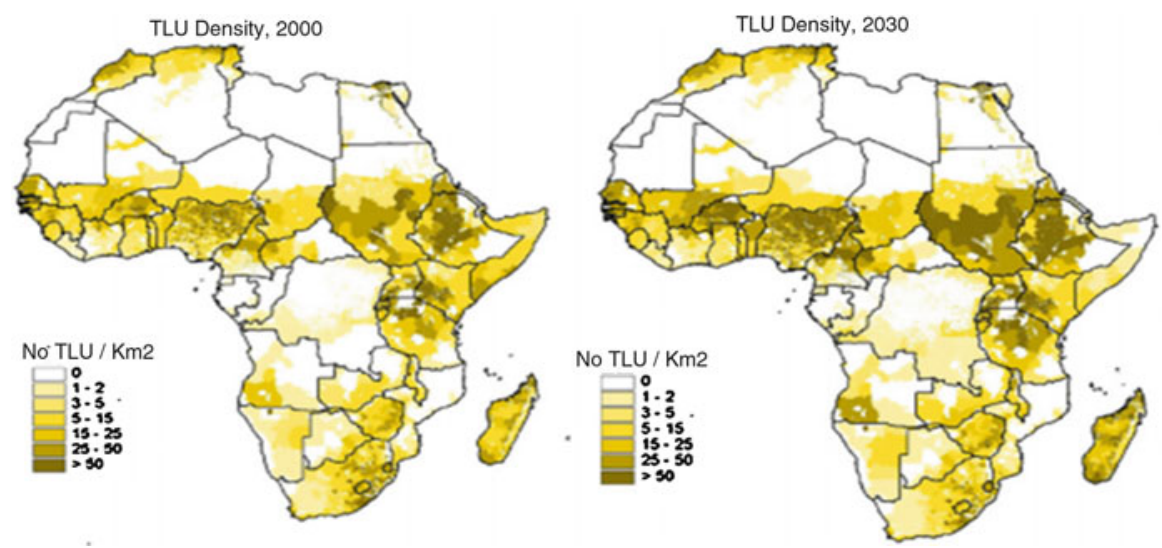

Fig. 2 Showing spatial distribution of livestock in Africa in the year 2000 and projected for 2030 (Herrero et al. 2008)

stomach of ruminants. This can be done through injecting/administering specific vaccines, drugs, or supplements that contribute to the reduction of methane. Other methods inlcude; biological methods can be adopted to reduce the ability of the livestock to reduce methane production in domesticated animals. For instance, the virus that attacks microbes in the rumen of the ruminants can be used to ensure animals produce less GHG. Methanotrophs which are microbes can also be introduced in the animals to help in the breakdown of produced into other wastes. The bovine somatotropin and hormonal growth implants is also a possible option but it does not suppress methane formation but rather improved the general performance of animals hence minimizing the intensity of GHG.

Manure management should be given priority as it is associated with significant amounts of $\mathrm{N}_{2} \mathrm{O}$ and $\mathrm{CH}_{4}$ during storage. However, the magnitude of the emissions varies depending on the structure. World over, there are no well-defined measures and policies of manure use and management since most of the grazing is done in open fields. For manure stored in lagoons or tanks, methane emissions can be minimized by covering or cooling of the sources. Other preliminary information has also suggested that covering manure heaps can significantly reduce $\mathrm{N}_{2} \mathrm{O}$ emissions (Dennehy et al. 2017). In addition, emissions from manure can be curtailed by altering feeding practices and also precision application when it comes to cropland. Methane digesters/anaerobic digester can also be used as an alternative strategy to the reduction of GHG although it is expensive to install. This is since maintaining anaerobic digester requires basic knowledge in wastewater and electrical generation hence high investment costs that can be managed by respective governments. Adopting anaerobic digestion offers an excellent strategy towards the reduction of the $\mathrm{CH}_{4}$ and $\mathrm{CO}_{2}$ to the ecosystem. The process offers natural existing bacteria that decompose organic matter resulting in biogas (Wang et al. 2017). In return, the biogas can be used to burn fuel and reduce emissions of GHG from fossils. Other practices that need to be put into consideration include: 
- Application placement (e.g., slurry injection)

- Application timing

- Application amounts (e.g., controlled rate systems)

- Export of manure (from the agricultural system)

GHG models can be developed at whole-farm level approaches to help in mitigation of various emissions specifically from daily farms. The advantage of using models in dairy farms is their ability to simulate calculations of $\mathrm{CH}_{4}$ and $\mathrm{N}_{2} \mathrm{O}$ emissions although the models may considerably vary but they give information on the current and future trends upon application of given measures.

Following the Intergovernmental Panel on Climate Change standard emission factors, it is confirmed that nitrogen deposited from urine and feces is converted to nitrous oxide twice the rate from the fertilizers used in farms. From the projections done for 2050, it is shown clearly that that in open pasture method, if no mitigation is put into practice, there is a possibility of having $25 \%$ increment on the emissions. In open field grazing strategy, the farmers can use chemical nitrification inhibitors as a way of preventing the transformation of the nitrogen is excreted in urine and feces to nitrous oxide. The other option is the introduction of biological nitrification, for example, use of the Brachiaria grass that has been reported to generate almost zero $\mathrm{N}_{2} \mathrm{O}$ emissions. Therefore, this a grass that the breeders can focus on to have the particular trait transferred in mostly grown grasses in pastures fields (Fig. 3).

Use of methane digesters is another excellent successful strategy for consideration in SSA but will require government intervention especially in extending facilities from e large to small scale farmers to be able to encourage innovation. The respective governments should come into a collaboration to develop the most cost-effective technologies and this can be achieved through funded programs by innovators. In addition, there is a need to have programs that will enable early detection and remediation of leakages from digesters. The collected manure can also be used to make biogas which provides an additional source of renewable energy hence has higher chances of reducing GHG emissions. This is an economical method since it will save the farmers from using fossil fuels in cooking since they can generate power from their farms. It is also feasible to acidify slurry produced mostly in the zero-grazing sectors to enhance to reduce conversion and formation of methane.

\section{Adopting Bioenergy as GHG Emission Reduction Strategy}

Crops and residues have high potential as sources of feedstocks for energy as a replacement of fossil fuels. Many of the materials that have been proposed for bioenergy role are grain, crop residue, cellulosic crops, and various tree species (Haberl et al. 2012). The advantage of these products is that they can be burned directly but later processed to generate fuel liquid. Although this process also produces $\mathrm{CO}_{2}$, it is associated with the original $\mathrm{CO}_{2}$ from the atmosphere for the process of photosynthesis hence displaces the $\mathrm{CO}_{2}$ that could be produced from fossils. The 


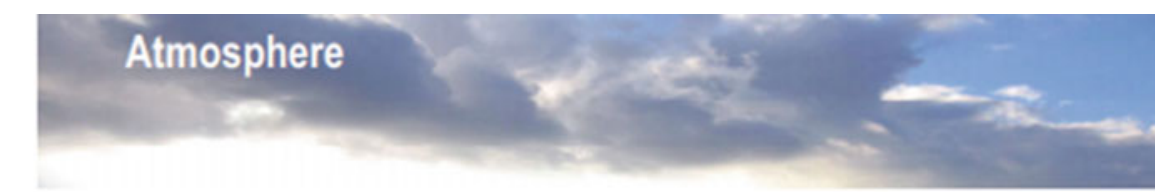

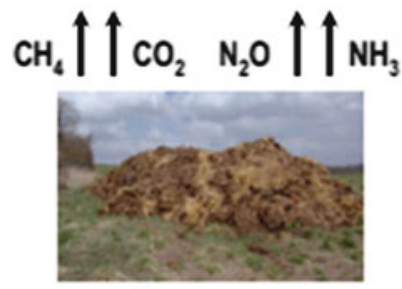

Manures (liquid \& solid)
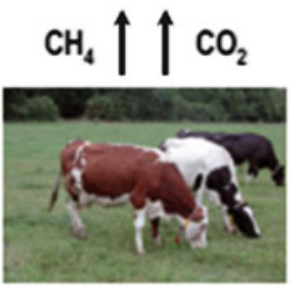

Cattle
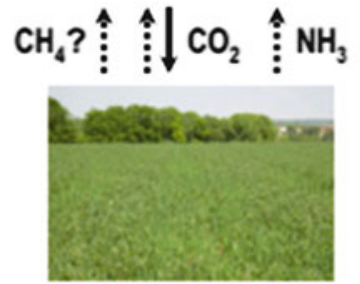

Vegetation

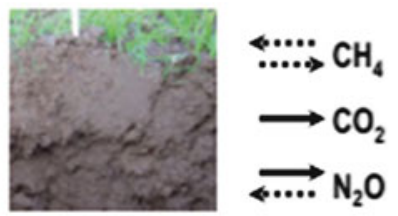

Soil

Fig. 3 Greenhouse gas and ammonia fluxes in the main compartments of a mixed crop-dairy system. (Adapted from Novak and Fiorelli 2010)

energy used in growing and processing the feedstock of bioenergy has a net benefit to the atmospheric $\mathrm{CO}_{2}$ (Eloka-Eboka et al. 2019). The existing interaction of an expanding bioenergy sector land use and other ecosystems services such as food production has not been exploited potentially; for instance, through assessment modeling, sub-Saharan Africa has been listed as one of the promising regions for bioenergy. It is estimated that in $2050,65 \%$ of the expected agricultural energy emissions will arise from farm energy use. In this regard, there is a need to reduce the amount of farm energy used from fossil to nonfossil use. Mitigation on the use of diesel fuels by tractors and other heavy equipment will be an effective move but requires transitions to hydrogen power that comes from solar and wind power. Also, battery-powered equipment and synthetic carbon-based fields will provide an alternative strategy. Use of these kinds of renewable energy in farms where mechanization is highly practiced will help in mitigating $85 \%$ of the total emissions from the synthesis of nitrogen fertilizers. Considering bioenergy as an option of mitigating GHG and saving our planet from climate change impacts, there is a need to make major transitions that are essential in exploiting the great potential of this particular source of energy (Smith et al. 2008). Bioenergy or use of biofuels implies a decrease in the dependence on fossil fuels and chemicals. The energy supplied from the use of plant-based fuels has the potential of decreasing GHG flow to the atmospheres. The biofuels will enable GHG mitigation through three key factors that include lower and 
competitive prices compared to fossil energy sources, ease in their production since the plants are grown during the entire year, and ecological and economic benefits of biofuels due to their environmentally friendly nature. Through these strategies, it will be efficient in mitigation of climate change effects in sub-Saharan Africa, though this will take longer to be achieved compared to other considered options.

\section{Reduction of GHG Through Genetic Selection of Animals}

Dairy is being one of the highest emitters of GHG to the atmosphere that requires critical strategies right from the selection of the best animals to reduce methane production. More focus should be put forward on the selection of cows that have less production of $\mathrm{CH} 4$ per unit according to Table 2. The impact of increasing genetic potential of the production stock is to increase the daily live weight gain of livestock for meat production or by nutrition hence leading to reduction of methane product per unity of the product. However, faster growth for slaughter implies that more feed will be needed to meet the required weight within a short time (de Haas et al. 2017). Therefore, this also means that the genetic selection has also to consider the type of grasses that can meet the requirements of such animals within the set time.

A high growth genotype leads to low emissions hence providing a promising measure towards mitigation of the climate change as a result of concentration in the atmosphere (Martinez-Fernandez et al. 2018). In addition, the use of environmentally fit genotypes is fundamental to increasing efficiency of converting feed to beef. In an experiment conducted in a farm in Northern Territory, methane production was lower by $31 \%$ in per tonne of the weaned weight within a given time because of a genetic characteristic of animals that can be weaned early to reduce the total emissions in the livestock sector (Mottet et al. 2017).

\section{Adopting to Isotopic Tracers in the Agricultural Field}

Stable isotopes that do not emit radiation such as nitrogen- 15 and carbon 13 on small experimental fields are good options. This method allows then to analyze the efficiency of the crops to consume nitrogen and the accumulation of carbon in the soils. For instance, nitrogen-15 technique is widely used by scientist to track and advise farmers on the amount of chemical fertilizer/manure needed by the plants as one of the ways to reduce increased emissions to the ecosystems (Slaets et al. 2016). Nitrogen-15 isotopic techniques can also be used by scientist to identify the sources of nitrous oxide in production and this forms an important pathway of reducing the emission of the gas to the atmosphere. Therefore, this technique has the potential of measuring the impact of climate and provides a way of mitigation.

Carbon-13 has also been used in the assessment of the soil quality by identifying the content of organic sources of carbon in the soil. This is also a crucial favor in promoting the optimal application of the agricultural practices hence reducing GHG emission. Stable isotope can also be essential in the generation of information on 
Table 2 Feeding strategy and genetic selection in the management of GHG emissions. (Adapted from Novak and Fiorelli 2010)

\begin{tabular}{|c|c|c|c|c|c|}
\hline \multicolumn{2}{|c|}{ Mitigation options for livestock management } & \multirow{2}{*}{$\begin{array}{l}\mathrm{CH}_{4} \\
\searrow ?\end{array}$} & \multirow{2}{*}{$\begin{array}{l}\mathrm{N}_{2} \mathrm{O} \\
-\end{array}$} & \multirow{2}{*}{$\begin{array}{l}\mathrm{CO}_{2} \\
-\end{array}$} & \multirow{2}{*}{\begin{tabular}{|l|}
$\mathrm{NH}_{3}$ \\
-
\end{tabular}} \\
\hline $\begin{array}{l}\text { Feeding } \\
\text { strategy }\end{array}$ & $\begin{array}{l}\text { Adding linseed lipids to the } \\
\text { diet }\end{array}$ & & & & \\
\hline & $\begin{array}{l}\text { Increasing the proportion of } \\
\text { concentrate in the diet }\end{array}$ & $\begin{array}{l}\searrow \text { from } \\
\text { animals } \\
\nearrow \text { from } \\
\text { slurry? }\end{array}$ & $\begin{array}{l}\nearrow \text { or } \\
\searrow ? \\
\text { (from }^{\text {from }} \\
\text { slurry }^{\mathrm{a}} \text { ) }\end{array}$ & $\begin{array}{l}\nearrow \text { (fossil } \\
\text { energy }+ \\
\text { soil) }\end{array}$ & $\begin{array}{l}\nearrow \text { or } \\
\searrow ? \\
(\text { from } \\
\text { slurry }^{\mathrm{a}} \text { ) }\end{array}$ \\
\hline & $\begin{array}{l}\text { Increasing the proportion of } \\
\text { maize silage in the diet }\end{array}$ & $\begin{array}{l}\searrow \text { from } \\
\text { animals }\end{array}$ & - & - & - \\
\hline & $\begin{array}{l}\text { Introducing legumes into } \\
\text { grazed grasslands }\end{array}$ & $\searrow$ & $\nearrow ?$ & $\searrow ?$ & $\nearrow ?$ \\
\hline & Limiting excess $\mathrm{N}$ in the diet & $\nearrow ?$ & $\searrow$ & - & $\searrow$ \\
\hline \multirow[t]{3}{*}{$\begin{array}{l}\text { Genetic } \\
\text { selection }\end{array}$} & $\begin{array}{l}\text { Selecting cows with low } \\
\text { enteric }\end{array}$ & $\searrow ?$ & - & - & - \\
\hline & $\mathrm{CH}_{4}$ production & & & & $\begin{array}{l}\searrow \mathrm{b} \text { or } \\
\nearrow ?\end{array}$ \\
\hline & Selecting high-yielding cows & $\begin{array}{l}\searrow \text { or } \\
\nearrow ?\end{array}$ & - & - & - \\
\hline \multirow[t]{2}{*}{$\begin{array}{l}\text { Herd } \\
\text { characteristics }\end{array}$} & $\begin{array}{l}\text { Reducing the replacement } \\
\text { rate }\end{array}$ & $\searrow ?$ & - & - & $\searrow$ \\
\hline & $\begin{array}{l}\text { Reducing the number of } \\
\text { milking cows }\end{array}$ & $\searrow$ & $\searrow$ & $\searrow$ & \\
\hline \multicolumn{6}{|c|}{$\begin{array}{l}\text { aDepending on the } \mathrm{N} \text { content of the concentrate compared to the roughage } \\
\text { "Results from Lovett et al. (2006) } \\
\searrow \text { : the mitigation option decrease the emissions } \\
\nearrow: \text { the mitigation option increase the emissions } \\
\text { "У or } \nearrow ": \text { both tendencies have been shown } \\
-: \text { no information was given on this compound } \\
0: \text { studies have shown that this option had no significant effect on this compound. } \\
\text { ?: the result needs to be confirmed by more studies. }\end{array}$} \\
\hline
\end{tabular}

GHG production and transport within a soil ecosystem. Importantly, stable isotopes have the potential of studying how GHG exchange with soils and atmosphere. This information is useful to enable researchers to understand the pathways of GHG, as well as the magnitude, as well as the magnitude is hence given rational recommendations (Zhu et al. 2019). However, this method is expensive and local farmers cannot afford to use to make various estimates. Therefore, the use of experimental reference sites can be useful in giving recommendations over a geographical position with similar activities.

\section{Management of Emissions in Rice by Adoption of Efficient Varieties}

Rice production in flooded or paddy rice contributes to at least $10 \%$ of global agriculture production. There are various suggestions that have high technical 
potential to mitigate rice emissions and that many of the options have a high potential of giving economic gains through yields and reduce the amount of water used in irrigation. Focusing on yield increase will give a promising measure towards reducing emission in rice production per unit area (Saha et al. 2018). This is in agreement with the FAO's forecast that increasing the rate of yield in paddy will also contribute to emission reduction in rice. Removing rice straws from paddies before reflooding to reduce methane production is also advised as one of the practices that farmers can embrace. The straws may be used for Bioenergy production (Joint 2018). Reducing the rate of flooding will reduce methane-producing bacteria where farmers can draw water down during the middle of the growing seasons. Another option is the beeding for rice varaities with lower emmissions of methane in the systems. Experiments in other regions such as China and Japan have shown that drawdown can reduce methane emissions by up to $90 \%$ (Müller et al. 2016). Use of the system of Rice Intensification that aims at reducing irrigation water at farm-scale is also an adaptable technique that farmers can use to minimize methane emissions in their rice fields. In rice irrigation, farmers should be advised to reduce the duration of flooding to minimize the populations of the methane-producing bacteria. In this regard, rice can be planted in a dry field other than flooding them and also they can reduce water during the middle days of the growing season. Breeding of lower methane rice will be another strategy that researchers should focus on to introduce both upland and lowland rice-growing irrigation systems. Water management in irrigation through the expanding area on irrigation could be more effective in increased carbon storage in the soils. Draining of agricultural fields in humid regions will help in suppressing $\mathrm{N}_{2} \mathrm{O}$ emission through improved aeration in soils. This strategy has been used in other regions such as China and Japan since it also increases yield and saves on irrigation water hence can also be adopted for the sub-Saharan Africa region.

\section{Development of Flexible Technology-Forcing Regulations}

The GHG emissions are strong issues that need to be regulated by the governments more so in sub-Saharan Africa counties where the governments have not invested much on controlling emissions due to their low-income capabilities. This is since if this issue remains a voluntary service, most of the individuals are not likely to take it as seriously as it is taken globally (Inglesi-Lotz and Dogan 2018). Therefore, there is a need to have flexible regulations that are designed to spur the technological development for the needed change. For instance, in case of fertilizer use, countries should develop regulatory systems that are similar to those developed in the United States or other places to increase the fuel efficiency of fleets of time (Nyamoga and Solberg 2019). Also, fertilizer manufacturers and importers will be required to sell fertilizers with increased efficiencies. Fertilizers regulation needed to be brought into consideration, for instance, the manufacturer should be barred from releasing any fertilizer product that does not have a coat to enhance its slow release and minimize $\mathrm{N}_{2} \mathrm{O}$ emissions in cropping systems. 


\section{Minimizing Enteric Fermentation and Food Wastes}

Enteric fermentation has the highest accountability of emissions from agriculture. It is part of the digestive systems of herbivorous animals that have a large fourcompartment stomach with a complex microbial environment that enables it to digest complex carbohydrates. The process of digestion produced methane as a byproduct hence contributing to its accumulation in the atmosphere. In this regard when animals are kept for long, the more they produce methane, and therefore, this should be shortened and ensure the levels of methane per production unit are minimal (Owen and Silver 2015). The three main existing options to mitigate this kind of fermentation and emissions are

1. Improving the quality and digestibility of feed

2. Providing supplements and additives and reduce methane

3. Optimizing the health and reproductive capacity of the herds

Food and Agriculture Organization (FAO) has approximated that food wastes contribute to almost a third of the world's GHG. This is more so in sub-Saharan Africa due to the culture of people holding a social gathering with several types of edibles available hence providing a wide range of choice. These foods are potential sources of GHG emissions with key gases produced being carbon dioxide, methane, nitrous oxide, and hydrofluorocarbons especially in countries without any existing policies on food loss and waste management (Capone et al. 2016). This calls for the development of a monitoring framework for developing countries especially in sub-Saharan countries through installing simple tools that can be used in the traceability of GHG emissions. According to the Intergovernmental Panel on Climate Change (IPCC), the lowering of food wastes will help in reducing the rate of GHG emissions and concentration in the environment. In this regard, there is a requirement for the respective government to come up with policies and campaign to enlighten the locals on the need to reduce their food wastes as one of the factors for environmental sustainability and to alleviate the serious threats of climate change that are currently experienced (Edenhofer et al. 2011).

\section{Use of Biochar to Minimize GHG Emissions}

Biochar is an organic material rich in carbon that is produced by the heating of biomass in the limited supply of oxygen. It is mainly produced as an additive to soils to improve nutrient retentions and carbon storage. In recent research, there has been growing interest in the use of biochar as an amendment to improve soil health, decrease net $\mathrm{N}_{2} \mathrm{O}$ emissions and methane, and to store carbon in the soils. Biochar has been recognized as one of the possible materials to enhance reduction of $\mathrm{CO} 2$ concentration in the environment. The advantage of biochar is sufficiently used to reduce GHG emission in the atmosphere for a prolonged time. It also allows a net reduction on the emissions in the entire lifecycle including both direct and indirect 
land uses (Kumar et al. 2020. It has been documented that biochar has the potential of reducing anthropogenic $\mathrm{CO} 2$ in the atmosphere by $12 \%$. Biochar has a low degradation process which helps in increasing its potential to store more carbon in the soils compared to other materials.

\section{Compositing of Solid Manure Before Applying to Crop Fields}

In many organic systems, composting of solid manure before applying to the field is encouraged. This method offers the advantage of producing a more stable product, free of weeds and toxins and easier to spread in the cropping systems. Through compositing it is subjects manure to the aerobic composition at temperatures of around $60{ }^{\circ} \mathrm{C}$. Since this method requires frequent turning of the heaps, the method makes it more vulnerable for $\mathrm{NH}_{3}$ losses; however, after application to the cropping fields, there are minimal losses since remaining $\mathrm{N}$ is mainly bound organically (Kumar et al. 2020). The mechanical turning of the composted manure is associated with lower $\mathrm{N}_{2} \mathrm{O}$ and $\mathrm{CH}_{4}$ compared to the anaerobic method; hence, this should be considered for the whole management systems right from manure storage to supplication to soils in the fields. It has been estimated that compositing lowers $\mathrm{N}_{2} \mathrm{O}$ and $\mathrm{CH}_{4}$ emissions; although significant amounts of $\mathrm{CO}_{2}$ are emitted during the composting process, it is not considered as a net source of $\mathrm{CO}_{2}$ in the entire agricultural chain. In addition, since composted manure is less degradable than fresh manure, application of this is a greater source of carbon storage in the soil and thus reduces the rate of $\mathrm{CO}_{2}$ emissions. The rapid incorporation of manure in the soils as an improved technique of application is associated with fewer emissions and is more cost-effective (Joint 2018). This kind of incorporation should be done during the first hours after application. Through this method, a significant $\mathrm{N}_{2} \mathrm{O}$ emissions in the soils will be reduced. Farmers should also consider using farmyard manure over liquid slurry for reduced GHG emissions.

In crop production as agriculture, subsystem offers various mitigation of greenhouse gases specifically the $\mathrm{CO}_{2}$ and $\mathrm{N}_{2} \mathrm{O}$ that are main gases in this level. The limitation of net $\mathrm{CO}_{2}$ can be achieved through increasing the rate of carbon storage to soils or by the plant. This is achieved through slowing return of stored carbon into the atmosphere via mineralization (Stanton et al. 2018). Most importantly, $\mathrm{N}_{2} \mathrm{O}$ mitigation should focus specifically on improving the nitrogen use efficiency of crops since $\mathrm{N}_{2} \mathrm{O}$ is generated from the soils. In crop production, farmers should also avoid compacting during tillage since this may increase $\mathrm{N}_{2} \mathrm{O}$ emission due to the conducive environment created for anaerobic zones within the soil structures. During the incorporation of plant, farmers should be advised to use plant contents with low $\mathrm{N}$ content since high $\mathrm{N}$ content in the tissue will trigger mineralization and denitrification that can alleviate the levels of $\mathrm{N}_{2} \mathrm{O}$ emissions. Tackling the interlinked problems on land degradation, climate change mitigation is a promising strategy that can produce promising results for both farmers and government (Zerhusen et al. 2019). 


\section{Integrated Farming Systems}

The integrated farming system is another way to reduce GHG emission and promotes the fight against climate change. The integrated systems are based on nuclear techniques that have been put into practice in some counties within sub-Saharan Africa including Kenya and Uganda. The practices are aiming at maximizing the recycling of nutrients that are found in animal manure and crop residues. This will ensure there is a reduction in the chemical fertilizers use and this will enhance the reduction of GHG from agricultural land (Stanton et al. 2018). This is a practical strategy since farmers can recycle nutrients as livestock mainly feeds on herbs and grasses that are excreted in form of manure then farmers can collect the manure and apply in fields, which is a way of returning many nutrients into the soil as illustrated in Fig. 4.

This strategy is feasible and practically possible in sub-Saharan Africa since it has been applied in other regions and does not require high investment but rather involves a set of regulations and extension to enlighten farmers on the benefits of

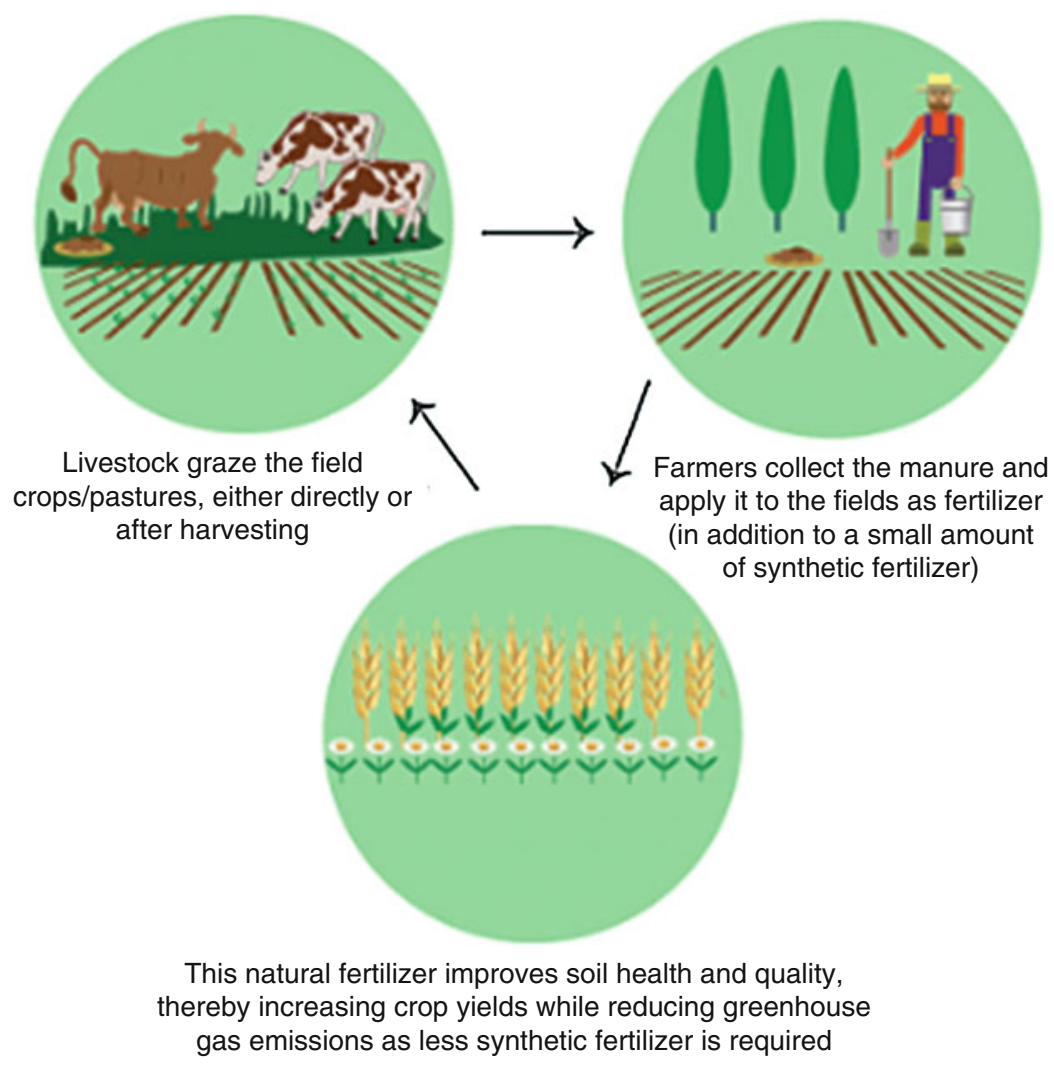

Fig. 4 Illustration of how an integrated system can reduce greenhouse gas emissions. (Adapted from Garnett 2011) 
this process. Integrated cropping-livestock practices have been used in Brazil and have given a successful out management plan in the use of land more efficiently. As a result, the GHG emission from urine and dung was reported to reduce by $89 \%$ from respective farms. Polyculture is another agronomic practice that can be used to mitigate emissions of GHG and help in combating the adverse effects of climate change. Polyculture entails growing of multiple crops in the same space to increase local biodiversity and increase the soil carbon. Agroforestry is another agronomic practice that can be encouraged as a strategy to minimize GHG emission in agriculture. This practice entails integrating crops or livestock and trees either for timber, firewood, or any other wood products. The agroforestry provides buffer strips in the riparian land as well as increasing carbon stock in the soils since they increase carbon sequestration hence emissions of $\mathrm{CO}_{2}$ to the atmosphere (Garnett 2011). Changes in consumption habits have substantial effects on the reduction of GHG emissions. Therefore, this calls for addressing how our food from agriculture is distributed across a supply chain. In particular, many of the environmental bodies have a recommended reduction of consumption of meat and other dairy products to enhance the reduction of GHG emissions from agricultural production. This implies that if consumers can adhere to this strategy and focus on well-grown crop products will have a significant effect on the overall concentration of GHG in the atmospheres. How this requires policy regulations and consumers' willingness to adapt to this kind of change. Although it is difficult to some communities that rear livestock as the main agricultural activity, they could be advised to minimize meat consumption, which may be from 5 to 2 days a week.

\section{Barriers to Mitigation GHG Emission and Climate Change in Sub- Saharan Africa}

Although there are various opportunities to combat GHG emissions and reduce impacts of climate in Africa, there are key barriers that may hinder adoption and achievement of these goals. There is a challenge on lack of awareness among the farmers on the bottom line impacts of climate change and causes that emanate from their cropping-livestock systems. A great population of the farmers in sub-Saharan Africa are not aware of the existing option, either high or low cost. This is since there is less focus on the ground level to address the issue; in this regard mitigation of GHG and reducing the impact of climate change more focus on starting ground level for the change to experience. Moreso, there is the existence of unsureness about the practicality of the available measure among the leaders and activist of climate change actions; hence, less awareness has been created to date. There is also the existence of complex interactions as farmers do not know the bottom line of the unintended consequences on the complexity of interaction during the adoption of what is believed to make a change to GHG emissions from agriculture (Mehra et al. 2018). Regulations and policies are also other barriers towards adoption and application of the existing measure. Some of the verification and regulation are quite expensive, and the fact that sub-Saharan Africa is a low-income region confirms the 
weight of the barrier. In addition, new regulatory regimes may require structuring the existing regulation before the implementation of proper governing policies.

Adopting some of the options may be against the social norms of the culture with diverse cultures being dominant in sub-Saharan Africa. For instance, manure management may be viewed as a dirty practice by some communities or religious beliefs hence making its management difficult. Besides, most farmers may fear loss aversion and may be adamant towards investing on best practices as advised by regulators. The existing extension services have the challenge of meeting farmers need and they create doubt on bits of advice they receive from them. Also, the government is slow in making clear on the role of extension officer and to what extent do they need to give communal seminars on critical issues such as climate change and GHG emissions (Allen et al. 2020). Development and transfer of technologies is another underlying barrier in the management of GHG emissions and mitigation of climate change. This is due to limited human and institutional capabilities to enhance proper dissemination of new information. Technological barriers exist in the limitation of generating and applying the developed solution to handle the problem. Technologies development and transfer remain crucial components for sustainable increase of productivity and mitigation of climate effects. Ecological barriers exist because mitigation potential in agriculture subsystems is mainly site-specific even within the same cropping systems. The limited resources in Sub-Saharan Africa pauses an ecological barrier towrads management of GHG and climate changes impacts. The frequent drought in Africa may limit the exact measurement and application of the mitigation measures at the farm level. In addition, due to high levels of poverty in the region, there is a likelihood that affording good equipment for mitigation will be hard hence have to rely on donors from other regions.

\section{Need for More Research}

Mitigation of GHG emissions is a critical area that currently requires a lot of investment in research, because these gases are complex and emitted from day to day activities that men perform to earn a daily living. Due to the adverse effects, they are causing damage to our ecosystems; identification of scientifically proven measures and option needs to be analyzed and scrutinized keenly through research. The researcher should focus more on agriculture although other sectors such as transport, energy, and industrialization have an equivalent measure. Although several measures have been documented to curb and minimize the rate of emissions, there is a need to have additional measures and strongly emphasize on their adoption through policy regulations. The research should focus on both generating new technologies and management systems with lower emission rates. Therefore, this requires the collaboration of governments in the sub-Saharan each to generate funds that can motivate and facilitate scientists in agricultural discipline to focus more on GHG about to actual quantification of the emissions as well as documenting available measures in the current context. Generation of more knowledge through research will provide cost-benefit analysis concepts to help in the assessment of the trade-off 
in the climate change mitigation options (Garnett 2011). The discoveries through research will enhance the provision of information and rationale on taking actions to mitigate GHG emissions. In addition, it will form a basis on informing decisionmakers and policymakers in the whole system.

\section{Conclusions}

In the light of adverse climate change effects being experienced in sub-Saharan countries currently, several opportunities to mitigate GHG in agriculture exist and can be realized through overcoming several barriers. There is a need to assign mitigation measures on the key causes of climate change hence more emphasis on greenhouse gases emitted from agriculture. The key GHGs $-\mathrm{CO}_{2}, \mathrm{~N}_{2} \mathrm{O}$, and $\mathrm{CH}_{4}$ - are not only produced in the farm setting but other sectors including energy, transport, and industries have a significant contribution. However, more potential lies in the agricultural sector that is widely spread in major regions of sub-Saharan Africa. Critical elements that require proper management are livestock systems and crop production that have shown to have the highest emission of the main GHG to the ecosystems. Therefore, to protect and improve the quality of our planet, there is a need to apply measures including manure management, improved fertilizer use efficiency, genetic selection of animals with less methane emission, minimizing enteric fermentation and floodwaters in agriculture and dairy subsystems. Developments of feasible and technological solutions to minimize GHG at small scale level, adopting bioenergy, growing of grass species with carbon sequestration effects, integrating crop-livestock system, and managing emission in paddy rice trough proper use of irrigation water and biochar application among others. Putting all measures discussed in the current chapter will help reduce the impacts of climate change in sub-Saharan and improve the quality of air and environment health in general. Regardless of several feasible options existing to mitigate GHG emissions and climate change in agriculture, to achieve these measures, there is a need for collaborative efforts between governments and the locals to carry out the required ground activities. There is the existence of certain barriers that limit the potential of management. Some of these barriers include policy and regulation, inadequate human and institutional capabilities, unstructured extension services, fear of loss aversion among farmers, and absence of platforms for disseminating new technologies. For any of the above-discussed measure, decision-makers need to make a consideration to the extent to which it moves away or closer to making the environment safer and still maintaining sustainable agricultural production with less GHG emissions.

\section{References}

Allen J, Pascual KS, Romasanta RR, Van Trinh M, Van Thach T, Van Hung N, Chivenge P (2020) Rice straw management effects on greenhouse gas emissions and mitigation options. In: Sustainable rice straw management. Springer, Cham, pp 145-159

Awazi NP, Tchamba MN (2019) Enhancing agricultural sustainability and productivity under changing climate conditions through improved agroforestry practices in smallholder farming systems in Sub-Saharan Africa. Afr J Agric Res 14(7):379-388 
Beach RH, Creason J, Ohrel SB, Ragnauth S, Ogle S, Li C, Salas W (2015) Global mitigation potential and costs of reducing agricultural non- $\mathrm{CO} 2$ greenhouse gas emissions through 2030. J Integr Environ Sci 12(sup 1):87-105

Capone R, Adriana C, Lee TKW (2016) Food losses and waste: global overview from a Mediterranean perspective. Mediterra 2016. Zero Waste in the Mediterranean. Natural Resources, Food and Knowledge/International Centre for Advanced Mediterranean Agronomic Studies (CIHEAM) and Food and Agriculture Organization of the United Nations (FAO)-Paris: Presses de Sciences Po, 193

Cassman KG, Dobermann A, Walters DT, Yang H (2003) Meeting cereal demand while protecting natural resources and improving environmental quality. Ann Rev Environ Resource 28:315358. https://doi.org/10.1146/annurev.energy.28.040202.122858

Cerri C (2010) Management practices for greenhouse gas emission reduction and carbon removal in Brazilian agriculture, livestock and forestry. Centro de Energia Nuclear na Agricultura/ Universidade de São Paulo, Piracicaba

Coskun D, Britto DT, Shi W, Kronzucker HJ (2017) Nitrogen transformations in modern agriculture and the role of biological nitrification inhibition. Nat Plants 3(6):1-10

de Haas Y, Pszczola M, Soyeurt H, Wall E, Lassen J (2017) Invited review: phenotypes to genetically reduce greenhouse gas emissions in dairying. J Dairy Sci 100(2):855-870

Dennehy C, Lawlor PG, Jiang Y, Gardiner GE, Xie S, Nghiem LD, Zhan X (2017) Greenhouse gas emissions from different pig manure management techniques: a critical analysis. Front Environ Sci Eng 11(3): 11

Edenhofer O, Pichs-Madruga R, Sokona Y, Seyboth K, Kadner S, Zwickel T, Matschoss P (eds) (2011) Renewable energy sources and climate change mitigation: special report of the intergovernmental panel on climate change. Cambridge University Press, Cambridge, MA

Eloka-Eboka AC, Bwapwa JK, Maroa S (2019) Biomass for CO2 sequestration encyclopedia of renewable and sustainable materials; Elsevier Inc. All rights reserved. https://doi.org/10.1016/ B978-0-12-803581-8.11029-X

Feng J, Li F, Zhou X, Xu C, Ji L, Chen Z, Fang F (2018) Impact of agronomy practices on the effects of reduced tillage systems on $\mathrm{CH} 4$ and $\mathrm{N} 2 \mathrm{O}$ emissions from agricultural fields: a global meta-analysis. PLoS One 13(5):e0196703

Galloway JN, Aber JD, Erisman JW, Seitzinger SP, Howarth RW, Cowling EB, Cosby BJ (2003) The nitrogen cascade. Bioscience 53:341-356. https://doi.org/10.1641/0006-3568(2003)053[ 0341:TNC]2.0.CO;2

García-Marco S, Abalos D, Espejo R, Vallejo A, Mariscal-Sancho I (2016) No-tillage and liming reduce greenhouse gas emissions from poorly drained agricultural soils in Mediterranean regions. Sci Total Environ 566:512-520

Garnett T (2011) Where are the best opportunities for reducing greenhouse gas emissions in the food system (including the food chain)? Food Policy 36:S23-S32

Garnett T, Godde C, Muller A, Röös E, Smith P, De Boer IJM, Van Zanten HHE (2017) Grazed and confused?: ruminating on cattle, grazing systems, methane, nitrous oxide, the soil carbon sequestration question-and what it all means for greenhouse gas emissions. FCRN, Oxford

Gibson AI (2002) Mitigation options for greenhouse gas emissions from agriculture. University of London, London

Haberl H, Sprinz D, Bonazountas M, Cocco P, Desaubies Y, Henze M, Lange E (2012) Correcting a fundamental error in greenhouse gas accounting related to bioenergy. Energy Policy 45:18-23

Herrero M, Thornton PK, Kruska R, Reid RS (2008) Systems dynamics and the spatial distribution of methane emissions from African domestic ruminants to 2030. Agric Ecosyst Environ 126(12): $122-137$

Hoekman SK, Broch A (2018) Environmental implications of higher ethanol production and use in the US: a literature review. Part II-biodiversity, land-use change, GHG emissions, and sustainability. Renew Sust Energ Rev 81:3159-3177

Huang R, Wang Y, Liu J, Li J, Xu G, Luo M, Gao M (2019) Variation in N2O emission and N2O related microbial functional genes in straw-and biochar-amended and non-amended soils. Appl Soil Ecol 137:57-68 
Inglesi-Lotz R, Dogan E (2018) The role of renewable versus non-renewable energy to the level of $\mathrm{CO} 2$ emissions a panel analysis of sub-Saharan Africa's Big 10 electricity generators. Renew Energy 123:36-43

Joint FAO (2018) Rice production guidelines: best farm management practices and the role of isotopic techniques (No. IAEA-TECDOC-1847). Joint FAO/IAEA Division of Nuclear Techniques in Food and Agriculture

Kumar S, Meena RS, Datta R, Verma SK, Yadav GS, Pradhan G, . . Mashuk HA (2020) Legumes for carbon and nitrogen cycling: an organic approach. In: Carbon and nitrogen cycling in soil. Springer, Singapore, pp 337-375

Leng LY, Ahmed OH, Jalloh MB (2019) A brief review on climate change and tropical peatlands. Geosci Front 10(2):373-380

Lovett DK, Shalloo L, Horan B, Dillon P, O’Mara FP (2006) Effect of Holstein-Friesian strain and feeding system on greenhouse gas emissions from pastoral dairy production systems. In: International Congress Series, vol 1293. Elsevier, pp 335-338

Malaka SF (2017) Estimation of greenhouse gas emissions from agriculture in the eastern Free State, South Africa (Doctoral dissertation, University of the Free State)

Martinez-Fernandez G, Duval S, Kindermann M, Schirra HJ, Denman SE, McSweeney CS (2018) 3-NOP vs. halogenated compound: methane production, ruminal fermentation and microbial community response in forage-fed cattle. Front Microbiol 9:1582

Mehra P, Baker J, Sojka RE, Bolan N, Desbiolles J, Kirkham MB, Gupta R (2018) A review of tillage practices and their potential to impact the soil carbon dynamics. In: Advances in agronomy, vol 150. Academic Press, pp 185-230

Mottet A, Henderson B, Opio C, Falcucci A, Tempio G, Silvestri S, Gerber PJ (2017) Climate change mitigation and productivity gains in livestock supply chains: insights from regional case studies. Reg Environ Chang 17(1):129-141

Müller A, Bautzen L, Meier M, Gattinger A, Gall E, Chatzinikolaou E, Ullmann L (2016) Organic farming, climate change mitigation and beyond. Reducing the environmental impacts of EU agriculture. IFOAM EU, Brussels

Mwanake RM, Gettel GM, Aho KS, Namwaya DW, Masese FO, Butterbach-Bahl K, Raymond PA (2019) Land use, not stream order, controls N2O concentration and flux in the upper Mara River basin, Kenya. J Geophys Res Biogeo 124(11):3491-3506

Novak SM, Fiorelli JL (2010) Greenhouse gases and ammonia emissions from organic mixed cropdairy systems: a critical review of mitigation options. Agron Sustain Dev 30(2):215-236

Nyamoga GZ, Solberg B (2019) A review of studies related to charcoal production, consumption, and greenhouse gas emissions in Tanzania. In: Agriculture and ecosystem resilience in Sub Saharan Africa. Springer, Cham, pp 357-399

Oberthür S, Hermwille L, Khandekar G, Obergassel W, Rayner T, Wyns T, and Melkie M (2019) Key concepts, core challenges and governance functions of international climate governance: deliverable 4.1; COP21-results and implications for pathways and policies for low emissions European societies

Owen JJ, Silver WL (2015) Greenhouse gas emissions from dairy manure management: a review of field-based studies. Glob Chang Biol 21(2):550-565

Paustian K, Larson E, Kent J, Marx E, Swan A (2019) Soil C sequestration as a biological negative emission strategy. Front Clim 1(8):1-11

Popp A, Lotze-Campen H, Bodirsky B (2010) Food consumption, diet shifts and associated non-CO2 greenhouse gases from agricultural production. Glob Environ Chang 20(3):451462

Ronaghi M, Saghaian S, Reed M, Mohammadi H (2018) The impact of the agricultural sector in developing countries that produce natural gas on greenhouse gas emissions. Int J Food Agric Econ (IJFAEC) 6(1128-2019-555):53-69

Saha S, Chatterjee D, Swain CK, Nayak AK (2018) Methane emission from wetland rice agriculture-biogeochemistry and environmental controls in projected changing environment. In: Advances in crop environment interaction. Springer, Singapore, pp 51-85 
Sanz-Cobena A, Lassaletta L, Aguilera E, Del Prado A, Garnier J, Billen G, Plaza-Bonilla D (2017) Strategies for greenhouse gas emissions mitigation in Mediterranean agriculture: a review. Agric Ecosyst Environ 238:5-24

Šimek M, Cooper JE (2002) The influence of soil pH on nitrification: progress towards the understanding of this interaction over the last 50 years. Eur J Soil Sci 53:345-354

Slaets J, Mayr L, Heiling M, Zaman M, Resch C, Weltin G, Dercon G (2016) Protocol development for continuous nitrogen- 15 measurement of $\mathrm{N}_{2} \mathrm{O}$ and its isotopomers for real-time greenhouse gas tracing

Smith P, Martino D, Cai Z, Gwary D, Janzen H, Kumar P, Scholes B (2008) Greenhouse gas mitigation in agriculture. Philos Trans R Soc B Biol Sci 363(1492):789-813

Stanton CY, Mach KJ, Turner PA, Lalonde SJ, Sanchez DL, Field CB (2018) Managing cropland and rangeland for climate mitigation: an expert elicitation on soil carbon in California. Climatic Change 147(3-4):633-646

Swamy M, Bhattacharya S (2006) Budgeting anthropogenic greenhouse gas emission from Indian livestock using country-specific emission coefficients. Curr Sci:1340-1353

Tongwane MI, Moeletsi ME (2018) A review of greenhouse gas emissions from the agriculture sector in Africa. Agric Syst 166:124-134

Wall E, Simm G, Moran D (2010) Developing breeding schemes to assist mitigation of greenhouse gas emissions. Animal 4(3):366-376

Wang Y, Dong H, Zhu Z, Gerber PJ, Xin H, Smith P, Chadwick D (2017) Mitigating greenhouse gas and ammonia emissions from swine manure management: a system analysis. Environ Sci Technol 51(8):4503-4511

Winnie N, Gweyi-Onyango J (2018) Biofertilizers as an alternative to inorganic fertilizers in sub-Saharan African: is the adoption the missing link? Eliexir Agric 114:49564-49551

Yang Y, Tilman D, Furey G, Lehman C (2019) Soil carbon sequestration accelerated by the restoration of grassland biodiversity. Nat Commun 10(1):1-7

Zerhusen B, Maze M, Effenberger M (2019) Hands-on model for assessing the green-house gas emissions and the fossil energy consumption of agricultural biogas plants. Landtechnik 74(5):118-134

Zhu XC, Di DR, Ma MG, Shi WY (2019) Stable isotopes in greenhouse gases from soil: a review of theory and application. Atmosphere 10(7):377

Open Access This chapter is licensed under the terms of the Creative Commons Attribution 4.0 International License (http://creativecommons.org/licenses/by/4.0/), which permits use, sharing, adaptation, distribution and reproduction in any medium or format, as long as you give appropriate credit to the original author(s) and the source, provide a link to the Creative Commons license and indicate if changes were made.

The images or other third party material in this chapter are included in the chapter's Creative Commons license, unless indicated otherwise in a credit line to the material. If material is not included in the chapter's Creative Commons license and your intended use is not permitted by statutory regulation or exceeds the permitted use, you will need to obtain permission directly from the copyright holder. 